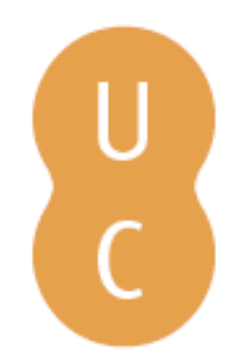

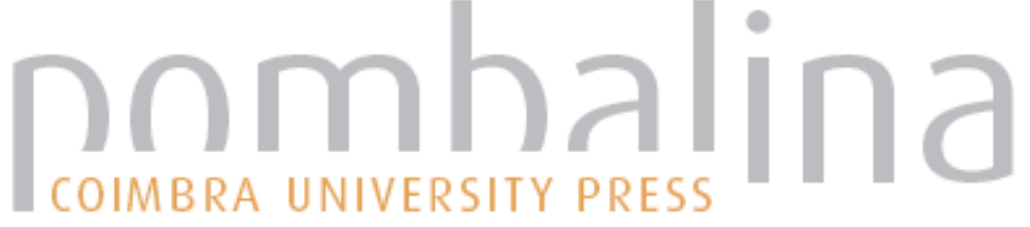

\section{From Linné to Darwin: the theories on the origin of species}

Autor(es): González Bueno, Antonio

Publicado por: Imprensa da Universidade de Coimbra

URL

persistente:

URI:http://hdl.handle.net/10316.2/31256

DOI:

DOI:http://dx.doi.org/10.14195/978-989-26-0342-1_3

Accessed : $\quad$ 26-Apr-2023 14:36:34

A navegação consulta e descarregamento dos títulos inseridos nas Bibliotecas Digitais UC Digitalis, UC Pombalina e UC Impactum, pressupõem a aceitação plena e sem reservas dos Termos e Condições de Uso destas Bibliotecas Digitais, disponíveis em https://digitalis.uc.pt/pt-pt/termos.

Conforme exposto nos referidos Termos e Condições de Uso, o descarregamento de títulos de acesso restrito requer uma licença válida de autorização devendo o utilizador aceder ao(s) documento(s) a partir de um endereço de IP da instituição detentora da supramencionada licença.

Ao utilizador é apenas permitido o descarregamento para uso pessoal, pelo que o emprego do(s) título(s) descarregado(s) para outro fim, designadamente comercial, carece de autorização do respetivo autor ou editor da obra.

Na medida em que todas as obras da UC Digitalis se encontram protegidas pelo Código do Direito de Autor e Direitos Conexos e demais legislação aplicável, toda a cópia, parcial ou total, deste documento, nos casos em que é legalmente admitida, deverá conter ou fazer-se acompanhar por este aviso.

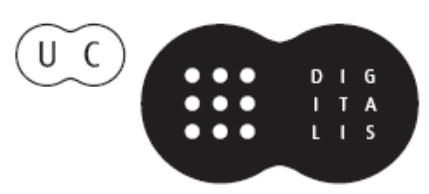


Ana Leonar Pereira João Rui Pita

Pedro Ricarda Fonseca (eds.)
Darwin,

Evalution,

Evolutionisms

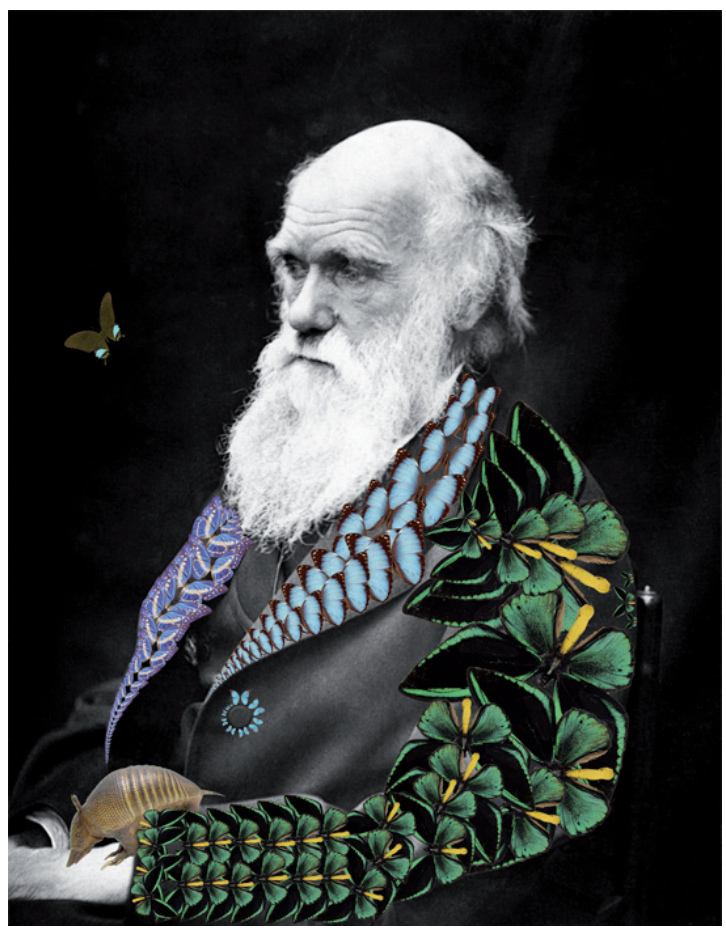




\section{From Linné to Darwin: the theories on the origin of SPECiES}

Between May and August of 1876, Charles Darwin recalled in the pages of his Autobiography:

"One day, as we were walking together, he [Robert Edmond Grant (1793-1874)] burst out in great admiration for Lamarck and his views on evolution. I listened in silent amazement, without being affected in any way emotionally. I had read my grandfather's Zoonomy earlier, and it had contained similar views. Nevertheless, it is quite probable that the fact that I was exposed at an early age to such views and heard them being praised made it easier for me to uphold the same ideas in a different form in my Origin of Species...."1

Which were the prevailing theories about the natural world at the moment in which Charles Darwin carried out his classical works? In which way did these ideas intervene in his thesis formulation? It is to these questions that I want to dedicate the following lines.

\section{From fixism to transformism}

The theories on the origin of the species, which prevailed well into the $18^{\text {th }}$ century, will maintain the immutability of the created forms: species are stable and unchangeable. In his Philosophia botanica... (Stockholmiae: apud G. Kiesewetter, 1751), Carl Linné (1707-1778) states: "Species tot sunt, qut diversas formas ab initio produxit infinitum ens" ${ }^{2}$. In this way, a creationist tradition, based on the literal interpretation of the Biblical Assumptions established in the Genesis is gathered.

The creationist idea of the natural world is even more clearly present in other works by Linné, especially in some geological essays and in his works about natural economy. Carl Linné outlined his concepts on the origin of the Earth in a short speech: Oratio de telluris habitabilis incremento... (Lugduni Batavorum: apud Cornelium Haak Leiden, 1743) in which, following the Biblical Doctrine, he imagined the existence of an Earthly Paradise

\footnotetext{
${ }^{1}$ Charles Darwin [José Luis Gil Aristu, trans.]. Autobiografía. [Pamplona]: Laetoli, 2008. Supplied text in Spanish on page 47.

${ }^{2}$ Cf. the aphorism 157 (page 99) in the Carl von Linné's edition Philosophia botanica, in qua explicantur Fundamenta Botanica. Stockholmiae: apud Godofr. Kiesewetter, 1751.
} 
situated on an island in Ecuador, in which animals and plants, confronting the scarcity of water, had started a progressive expansion, colonising the rest of the Planet. This is a speech in which he clearly expresses his approaches and ideas about Nature's harmonic balance, in accordance with the perfect proportion established in the Holy Scriptures.

This concept about natural harmony acquires even greater dimensions in the academic dissertations defended by his disciples on his economic vision of Nature, such as Oeconomia naturae... (Upsaliae: [s.n.], [1749]) or Politia naturae... (Upsaliae: [s.n.], [1760]), which is conceived as an eternal cycle in which the death or birth of each living being occupies a specific place within a global model perfectly defined, clearly reflecting the Divine Plan of Creation.

The accumulation of materials, especially during the elaboration process of Species Plantarum... (Holmiae: impensis L. Salvii, 1753), will modify this fixist theory clearly defended in his first works coming closer to new concepts in which species are interpreted as entities formed after the moment of Creation, through hybridism: a hypothesis whose draft can be found in previous texts like his Dissertatio botanica de Peloria... (Upsaliae: [s.n.], [1744]) in which he described a monstrous form of the Linaria vulgaris L., interpreted by him as a hybrid between a specimen of Linaria L. and a completely different plant. These and other observations led him to maintain that the development of new plant species through hybridism was possible, a theory developed in the Plantae hybridae... (Upsaliae: [s.n.], 1751). In other reports such as Disquisitio de sexu plantarum... (Petropoli: [s.n.], 1760) and Fundamentum fructificaciones... (Upsaliae: [s.n.], 1762) you can clearly find this new line of thought to which Carl Linné arrives at through his own observation. After broadening it, he sustained the risky hypothesis that all the plants of one same gender derived from a single species, the one created by Divine Decision, and that the remaining species of that gender have been formed through hybridism processes that have occurred between the primary species and others of different genders. This is a theory that develops similar principles to those defended by Andrea Cesalpino (1519-1603) to explain the variability of Nature. In the last years of his life, around 1760, Carl Linné magnified his hypothesis up to the point of maintaining that, at the moment of Creation, only one specimen for each order existed, generating the rest through hybridism processes implying the acceptance of a variation of Nature, in time as well as in space.

This was not a new idea; the botanist Jean Marchant (f. 1738) had already exposed a similar hypothesis in 1719, at the Académie Royale des sciences in Paris:

"Through this observation [he writes referring to a pyloric mercurial], there are reasons to think that the Divine Omnipotence has created plant individuals as models for gender formed through imaginable structures and features, capable of reproducing like the model (...) or types of each gender, in order for them to perpetuate, have finally produced varieties, among which those that have stayed constant and permanent, form species. These species, with time, and in the same way, have given way to different productions with which Botany has increased in certain genders..."3

\footnotetext{
3 Jean Marchant. "Observations sur la nature des plantes". Mémoires de Mathématique et de Physique, tirez des registres de l'Académie Royale des Sciences de l'Année MDCCXIX. Paris, 1721. About this author and his contributions to this area, $c f$. Henri Hus. "Jean Marchant; an Eighteenth century mutationist".
} 
Thus, from the strictest fixist approaches there seems to be a particular accepted transformist hypothesis, limited to the permitted progress measured by the creation order.

This interest in the origin of the species is not only limited to the scientific circles. In 1745 Pierre Louis Moreau de Maupertuis (1698-1759) had his Vénus Physique... ([Paris: s.n.], 1745) ${ }^{4}$ printed, a booklet halfway between scientific diffusion, literary gossip, experimentation, erotic fiction and philosophy, so common to that 'underground' literature of the Old Regime'. The small piece of work was an editorial success, for in 1751 it was already in its sixth edition leading the sarcastic Voltaire to state that Maupertuis' 'Venus' was in everyone's hands. ${ }^{6}$

If we bring this text into consideration, a story that takes place in the middle of one of the Parisian rooms, presided over by a woman with intellectual aspirations, a fact that emphasises the non-academic character of the story, it is because of the commentaries the author makes on the processes of production of new species in Nature. Referring to the case of albinism in the black race, the real generator of his article, he will write:

"It's a four or five-year-old boy that has all the features of black people but who's very livid skin only increases his ugliness. His head is covered in a white, turning to red, wool. His light blue eyes seem to be hurt by the clearness of the day. His hands, thick and badly formed, look more like an animal's legs than the hands of a man. He was born, according to what has been assured, from an African father and mother, who were very black (...)

These changes in colour are more frequent in animals than in men. The colour black is as inherent in vultures and blackbirds as it is to black people. However, I have sometimes seen white vultures and white blackbirds. In fact, these variations would form new species, if they were cultivated. I have seen regions in which the hens were white. The whiteness of their skin, ordinarily linked to the whiteness of their feathers, has caused the preference for these hens and not others and, from generation to generation it has lead to seeing only white hens (...).

The American Naturalist, 45(536): 493-506. Chicago, 1911, who translates into the English language Jean Marchant's booklet ( $c f$. pages 501-506 and who we follow in the transcribed paragraph; page 506-).

${ }^{4}$ Previously partially published in an anonymous way, [Pierre Louis Moreau de Maupertuis]. Dissertation physique a l'occasion du negre blanc. Leiden: [s.i.], 1744. A detailed study about the biological ideas of this author in Michael H. Hoffheimer. "Maupertuis and the Eighteenth-Century Critique of Preexistence". Journal of the History of Biology, 15(1): 119-149. Boston, 1982.

${ }^{5}$ An analysis of Maupertuis' work, in which his scent for the 'subversive and clandestine literature' in Mary Terrall is discovered. "Salon, Academy, and Boudoir: Generation and Desire in Maupertuis's Science of Life". Isis, 87(2): 217-229. Chicago, 1996. On this type of literature cf. Robert Darnton. The literature underground of the Old Regime. Cambridge [Mass.]: Harvard University Press, 1982; Ibid., The forbidden bestsellers of pre-revolutionary France. New York: Norton, 1994.

${ }^{6}$ Cf. Nelson Papavero and Jorge Llorente-Bousquets, Principia taxonómica: una introducción a los fundamentos lógicos, filosóficos y metodológicos de las escuelas de taxonomía biológica. 4. El sistema natural y otros sistemas, reglas, mapas de afinidades y el advenimiento del tiempo en las clasificaciones: Buffon, Adanson, Maupertuis, Lamarck y Cuvier. [México]: Universidad Nacional Autónoma de México, Facultad de Ciencias, Coordinación de Servicios Editoriales, 1994. $c f$. page 51. 
If there is a necessity to find out what occurs in plants in order to confirm what I say here, those who cultivate them would say that all plant and plumed small tree species which are admired in our gardens are due to different varieties which have become inherited. These can disappear if we forget to take care of them..."7

In Maupertuis' text we can see the presence of Nature's capacity to produce changes and to conserve them. He makes reference to 'unforeseeable productions' favoured by artificial selection and which can disappear through Nature but also know the way of forcing the process and are able to perpetuate these 'unforeseeable productions': those generations only have to repeat themselves several times and, in that way, man acts on the beings that he modifies in pursuit of a strange concept of beauty which borders the exotic or the abnormal.

A not so different attitude to this was the one defended by Georges Louis Leclerc, Comte de Buffon (1707-1788), member of the Academie des Sciences of Paris and head of the Jardin du Roi, the French institution par excellence, dedicated to Natural History. Buffon, not an advocate of the systematic theories defended by Carl Linné, understood the species as stable entities in which the features continue from generation to generation and among which there is a possibility of obtaining fertile descendents. However, his experience distanced him from the dominant creationist perspective. He was the first Christian European to publicly consider that the Earth's age was far older than the one established by the theory defended by the Ecclesiastic authorities of his time: the four thousand and four years Before Christ.

Comte de Buffon was the author of an extensive work, the Histoire naturelle, générale et particuliére, avec la description du Cabinet $d u$ roy. (Paris: Imprimerie royale, 1749-1804. 44 vols.), an effort to make accessible, in a synthesised manner, all the available scientific knowledge. We owe the term 'degeneration' to Comte de Buffon. According to his theory, presented in 1766 in volume XIV of his Histoire naturelle..., in the chapter dedicated to "De la dégénération des animaux", the related species have a common 'unity of type', from which they branch off. The concept of 'degeneration', using it in the sense given by Buffon, does not suppose the loss of the structural complexity, it supposes a common origin. Buffon admitted that the natural environment could cause an influence on living beings, causing forced variations of temperature or nutrition, but he also thought that these variations were not long-lasting and that, when the conditions that forced these varieties disappeared, the species would once again obtain their previous structure.

Buffon did not deny the Creator Principle but he did deny the direct intervention of the Maker in each of the species that form Nature. He would maintain that God is not personally in charge of the folding of each wing of a beetle. These are 'secondary causes' which he did not know how to specify but to which he attributed natural features, those that are in charge of organising these structures. Even though he examined some ideas, he never formalised a hypothesis about the origin and evolution of species, in the way in which Chevalier de Lamarck would do.

${ }^{7}$ Pierre Louis Moreau de Maupertuis. Op. cit. (Cf. Nelson Papavero and Jorge Llorente-Bousquets, op. cit., pages 81-82 supplied text in Spanish). 


\section{Lamarckism}

This capacity of the natural forms to transform themselves and to perpetuate the changes which they acquired is underlying in Jean Baptiste de Monet (1744-1829), Chevalier de Lamarck's thoughts. In his opinion, the species is only provisionally stable, with an innate availability to change, depending on the environment in which it is developed:

"Those who have observed and consulted the great collections ended up convincing themselves that, the same as the circumstances of habitat, exposure, climate, food, habit of living, etc., (...) the characteristics of size, form, proportion of parts, colour, consistency, agility and industry in animals proportionally change..."

In this way, the environmental changes cause transformations in living beings, transformations that eternalize to the extent in which the changes of its habitat conditions are stabilised.

"It is not the organs: nature and the form of the parts of an animal's body which have given place to their habits and their particular features, but on the contrary, the habits, the way of living and the circumstances in which the individuals they come from have lived, are what, with time, have constituted the form of their body, the number and state of an organ and the capabilities, which they enjoy..."

The book Philosophie zoologique... (Paris: chez Dentu, 1809), in which these postulates show their most radiant expression, is full of examples. Let us recall the most classical ones:

"In relation to habits it is curious to observe the product in the particular form and height of the giraffe. It is known that this animal, the tallest of the mammals, lives in the interior of Africa, in which the arid region without prairies makes them browse among the trees. Of this habit, maintained after much time in all the individuals of its race, we have the result that its front legs have become longer than its back legs and its neck has elongated in such a way that the animal, without rising on his back legs, raises its head and reaches about six metres high" 10 .

"The bird, to which the necessity attracts towards the water to find in it the prey which will feed it, separates the fingers of their legs when it wants to strike the water and move on its surface. The skin that links its fingers in the base contracts and, due

${ }^{8}$ Jean Baptista de Monet [Lamarck]. Philosophie zoologique... Paris: chez Dentu, 1809. [Spanish edition from José González Llama, printed in Valencia: Editorial Sempere, 1910] $c f$. page 170, supplied text in Spanish.

${ }^{9}$ Cf. page 177 from the Spanish edition from Jean Baptista de Monet [Lamarck] cit. ut supra, an idea that, as the own author recognises, is already present in Recherches sur l'organisation des corps vivants, et particulièrement sur son origine, sur la cause de son développement et des progrès de sa composition... Précédé du discours d'ouverture du cours de Zoologie donné dans le Muséum d'histoire naturelle... Paris: chez l'auteur [Maillard], l'an X de la République [1801-1802]

${ }^{10}$ Cf. page 187-188 of the Spanish edition from Jean Baptista de Monet [Lamarck] cit. ut supra. 
to such non-stop and repeated deviations, the habit of extending itself. That's why, with time, they have formed broad membranes that link the fingers of ducks, geese, etc."11.

"Is there any example more surprising than the one that the kangaroo offers? This animal, which takes its breeding in the bag that it has under its abdomen, has acquired the custom of standing up, only on its back legs and on the tail, and walk jumping maintaining a straight attitude in order not to hurt its siblings. Here, the result: its front legs, very sporadically used, have not acquired a proportionate development in relation to the rest of its parts, becoming very small, very weak and almost without any strength. On the contrary, the back legs, almost always in action, have achieved a considerable development, being very big and strong. Lastly, the tail, which the animal uses to carry out its main movements, has acquired a considerable strength and thickness in its base. These very well known facts are very appropriate to demonstrate what animals undertake through the use of any organ..."12.

The examples can be multiplied, but I think that these extensively prove the reasoning exposed by Chevalier de Lamarck in order to sustain his hypothesis which, even though signalled by Charles Darwin as one of his precedents ${ }^{13}$, had, in his time, a scarce scientific and social reception.

Lamarck's theory comes from a basic premise: Nature's progressive complexity. In Lamarck's opinion, the simplest forms of life are born by spontaneous generation and an internal fluid system (which acts over and is the origin of the different organs, which are more and more complex). In this process of the 'path towards complexity', we can see that the environmental conditions are capable of modifying the habits of the living beings and, with that, their organs' activities, developed or atrophied, according to the use and which then perpetuate through reproduction.

"If it is common to the individuals that in fertilisation come together to the reproduction of its specie, all change obtained in an organ produced by its continuous habit of having it in action is immediately conserved by the next generation. In sum, this change advances and passes on to all the individuals which follow and find themselves submitted to the same circumstances, without having seen themselves in the obligation to acquire them through the way in which it had really been created"14.

${ }^{11}$ Cf. page 183 of the Spanish edition from Jean Baptista de Monet [Lamarck] cit. ut supra.

${ }^{12}$ Cf. page 188-189 of the Spanish edition from Jean Baptista de Monet [Lamarck] cit. ut supra.

13 Charles Darwin valued Chevalier de Lamarck's works in the historic preface that, since the April 1861 edition, has preceded On the Origin of Species...: "Lamarck was the first whose conclusions on this point caused great attention (...). In relation to the modification forms, he attributed some part to the direct action of the physical conditions of life, some on the growth of already existing forms and a lot to the use and disuse, this is, the effects of the habit (...). Besides this, he also believed in the progressive development law: and as all the forms of life tend to progress, in order to explain the existence of simple production in the present days, he maintains that these are spontaneously generated..." ( $c f$. page 2 [text in Spanish] of the Charles Darwin edition [Enrique Godínez, trans.]. Origen de las especies por medio de la selección natural ó la conservación de las razas favorecidas en la lucha por la existencia... Madrid / París: Biblioteca Perojo, 1877).

${ }^{14}$ Cf. page 190 of the Spanish edition from Jean Baptista de Monet [Lamarck] cit. ut supra. 
In his Système des animaux sans vertèbres... (Paris: chez l'auteur, 1801), considered by some authors as the 'birth certificate' of Lamarckism ${ }^{15}$, Chevalier de Lamarck argued that the existence of life on Earth went back several thousand of millions of years, thus solving an apparent contradiction: we do not see a variation in the species and, however, they do have it; a variation that is very slow in relation to the humans' perception scale but which can be perceived in the scale of geological time.

Of course, Charles Darwin's mention of Lamarckist assumptions is more rhetoric than real. In a letter to his cherished friend Joseph Dalton Hooker (1817-1911), dated as early as January 11 th 1844 , he wrote:

"Besides a general interest about the Southern lands, I have been now ever since my return engaged in a very presumptuous work $\&$ which I know no one individual who wd not say a very foolish one.

I was so struck with distribution of Galapagos organisms \&c \&c \& with the character of the American fossil mammifers, \&c \&c that I determined to collect blindly every sort of fact, which cd bear any way on what are species.

I have read heaps of agricultural $\&$ horticultural books, $\&$ have never ceased collecting facts.

At last gleams of light have come, \& I am almost convinced (quite contrary to opinion I started with) that species are not (it is like confessing a murder) immutable. Heaven forfend me from Lamarck nonsense of a 'tendency to progression' 'adaptations from the slow willing of animals' \&c, - but the conclusions I am led to are not widely different from his - though the means of change are wholly so - I think I have found out (here's presumption!) the simple way by which species become exquisitely adapted to various ends.

You will now groan, \& think to yourself 'on what a man have I been wasting my time in writing to.' $-\mathrm{I} \mathrm{sh}^{\mathrm{d}}$, five years ago, have thought so..." 16 .

And, in a letter to the same correspondent on November 10th 1844, he would not vacillate at the moment of writing:

"With respect to Books on this subject, I do not know of any systematical ones, except Lamarck's, which is veritable rubbish..."17.

\section{The contributions of Comparative Anatomy}

In Napoleonic France, in the beginning of the $19^{\text {th }}$ century, the re-founded Muséum d'Histoire Naturelle would see the birth of a discipline which would

${ }^{15}$ Cf. Franck Bourdier. "Lamarck et Geoffroy Saint-Hilaire face au problème de l'évolution biologique". Revue d'Histoire des Sciences, 25(4): 311-325. Paris, 1972.

${ }^{16}$ Cf. letter 729 in Darwin correspondence project. [http://www.darwinproject.ac.uk/] [consulted on IV-2008].

${ }^{17}$ Cf. letter 789 in Darwin correspondence project. [http://www.darwinproject.ac.uk/] [consulted on IV-2008]. 
bring new light to the dark mystery of the origin of species: we are speaking of Comparative Anatomy.

The abundant studies which on the similarities between animal skeletons were quite old. Pierre Belon (1517-1564) had already established, in 1555, the concordance between human and bird skeletons, but the academic maturity of this discipline would only take place in the beginning of the $19^{\text {th }}$ century by Georges Cuvier, (1769-1832), thanks to his ability to summarise the contributions of taxonomy and palaeontology.

In Cuvier's thoughts, the functional disposition of the animal's organs responds to its life's conditions. Carnivores, who need to locate, catch and tear its prey, need visual keenness, limbs suitable to run and jaw bones and teeth suitable to tear. On the contrary, herbivores do not have any claws in their limbs and these are substituted by hooves, and their jaws and teeth are adapted, the same as their stomach, to the food which they are to ingest and digest. These ideas, which he theoretically organised in his 'principle of parts correlation', are linked to a 'principle of function dependence', in which he establishes a hierarchic structure of the functions which will develop the organism, in contrast to those that form the functions of the nervous system.

In his classificatory model, Cuvier states that the weight of the feature is determined by its functional importance and in that way establishes an order in the animal kingdom in four great morphological types: vertebrates, articulated, mollusks and radiates, among which there are no intermediate forms. The establishment of these four great organisation plans, isolated among each other, supposes a rupture against the conceptions of a 'Natural chain' defended by Lamarck and other naturalists, in which all living beings share a common model from which their development begins.

In Cuvier's discourse, the study of an American fossil, the Megatherium, has a special impact: the comparative works about structure which internalised the South American sloths along with other fossil rests of Siberian mammoths, compared to the actual elephants, led him to maintain that the extinction of these beings was due to conditions that he considered as abrupt changes in Nature. This is a contradictory attitude to what Chevalier de Lamarck defended: slow adaptation. The living beings plastically modelled by environmental conditions, as Lamarck had described, turn into stabilised structures, with firmly fixed features, which only great environmental catastrophes, such as the Flood, can wipe off the face of the Earth.

Chevalier de Lamarck and Baron Cuvier shared the same space, but not the same ideas ${ }^{18}$, in the Muséum d'Histore Naturelle in Paris. Along with them, Etienne Geoffroy, also known as Geoffroy Saint-Hilaire (1772-1844) was in charge of, after the transformation occurred in the Jardin des Plantes in June 1793, of the official chair of the zoology of vertebrates.

Geoffroy's works on Comparative Anatomy go in a different direction than that maintained by Cuvier, closer to the traditional line defended by Comte de Buffon, inspired on the search of a prototype, of a single composition plan, aside from form or organ functionality. In his analysis on the similarity and homology among organs, he called upon the study of embryonic forms which appears in Philosophie

\footnotetext{
18 The lecture of the "Éloge de Lamarck" done by George Cuvier is very illustrative in relation to this topic (Recueil des Éloges Historiques: 179-210. Paris: Didot, [1832], 1861).
} 
anatomique... (Paris: Méquignon-Marvis, 1818). For example, the similarity among the number of pieces in bird and fish skulls and among these and human embryos. The results lead him to formulate an 'economic principle of nature' according to which the development of an animal structure leads to the atrophy of another ${ }^{19}$. His latest works on the exoskeleton of insects and vertebral columns, published in 1820 , intensify this formulation of structural unity, until then restricted to animals with vertebras ${ }^{20}$.

This idea of searching for the prototype has a strong connection with the German Naturphilosophie. In Versuch die Metamorphose der Pflanzen zu erklären (Gotha: bey Carl Wilhelm Ettinger, 1790) Johann Wolfgang von Goethe (1749-1832) argued that the different parts of the vegetables could be considered as modifications of a unique utopian base structure which he considered an 'ideal leaf'.

But let us return to Paris, at the beginning of the $19^{\text {th }}$ century, in order to attend the public debate between Cuvier and Geoffroy in March 1830; a debate which left a lively impression on Goethe, up to the point of making him go back to his works on Comparative Anatomy ${ }^{21}$. There, in the Academie des Sciencies, Cuvier mentioned the necessity of having to comply with the facts and avoid hypothetical theoretic constructions like the 'Natural Chain' defended by Lamarck or the 'composition unity' defended by Geoffroy. In his formulation there was a strong religious content making pressure: Creation could not constrain to a single organisation plan. On his side, Geoffroy argued the naturalist's liberty to formulate general theories and interpret the observations according to his own beliefs. The debate reached the press and the omnipotent and elder Cuvier had to count on the support of the most conservative publications to confront the liberal newspapers that showed his opponent, Geoffroy, as a warlord of the liberty of thought, opposed to the rigid structure defended by the academic stalls ${ }^{22}$.

The studies on Comparative Anatomy in Great Britain have their maximum representation in the works of the powerful Richard Owen (1804-1892), who Charles

19 Théophile Cahn has taken care of the relation between Etienne Geoffroy's studies and the evolution theory. "L'oeuvre d'Etienne Geoffroy Saint-Hilaire dans une perspectiva de l'evolution de la pensée scientifique”. Revue d'Histoire des Sciences, 25(4): 301-310. Paris, 1972. The 'understanding' among the theories maintained by Etienne Geoffroy on animal structures, by Valentin Haüy on minerals and Agustin De Candolle on vegetables, has been analysed by F. Dagognet. "Valentin Haüy, Etienne Geofroy Saint-Hilaire, Agustin P. de Candolle: Une conception d'ensemble mais aussi un ensemble de conceptions". Revue d'Histoire des Sciences, 25(4): 327-336. Paris, 1972

${ }^{20}$ Etienne Geoffroy Saint-Hilaire. "Sur un squelette chez les insectes, dont toutes les pièces, identiques entre elles dans les divers ordres du système entomologique, correspondent à chacun des os du squelette dans les classes supérieures, Lu à l'Académie des Sciences, le 3 janvier 1820". Annales générales des sciences physiques 5: 96-132. Paris, 1820.

21 "At the end of this year [1831] and beginning of the next [1832], Goethe started once again to fully dedicate himself to his favourite studies, Natural Science (...) especially due to his interest on the debate between Cuvier and St. Hilaire on different topics related to plant metamorphosis and the animal world..." (Cf. Johann Peter Eckermann [Rosa Sala Rose, ed.]. Conversaciones con Goethe en los últimos años de su vida. Barcelona: Acantilado, 2005; quote from pages 578-579 [text in Spanish]; the controversy will be analysed again on page 801 ).

22 Jean Piveteau. "Le débat entre Cuvier et Geoffroy Saint-Hilaire sur l'unité de plan et de composition”. Revue d'Histoire des Sciences, 3(4): 343-363. Paris, 1950; Toby A. Appel. The Cuvier-Geoffroy debate, french biology in the decades before Darwin. New York: Oxford University Press, 1987. 
Darwin met and even visited with certain frequency during his years as a Londoner and who would even make him suffer with his critics ${ }^{23}$. Richard Owen's Lectures on the comparative anatomy and physiology of the vertebrate animals (London: Longman, Brown, Green \& Longmans, 1843) and his contemporary presentation of the vertebrates' prototype ${ }^{24}$, accepting the scheme defended by Cuvier, represent the theoretical base that prevailed at the moment of the publication of The Origin of Species...

\section{From the 'geological flood' to actualism}

During the last years of the $18^{\text {th }}$ century, the history of the Earth and the history of living beings, up to then travelling through different pathways, converged in their courses. The connecting link were the fossils. The triumph of Georges Cuvier's catastrophic theories over the transformist conceptions of Chevalier de Lamarck's ideas was due, mostly, to the increase of the fossil record. Against the abundant invertebrates, particularly molluscs, of the records near Paris, that turned out to be very useful at the time of completing the series established by Lamarck, the emergence of the remains of vertebrates which were hard to locate on the scale of Nature backed up the catastrophic hypothesis. However, all the theories had their audiences.

Towards the central years of the $19^{\text {th }}$ century, Isidore Geoffroy Saint-Hilaire (1805-1861), son of Étienne Geoffroy, through the study of animal breeding in domestication and of the acclimatisation of species, reformulated his father's and Chevalier de Lamarck's theories, favourable to selective variation. On their side, the supporters of Natural Theology, rebuking the perfection of the creational order, exposed the perfect adaptation of the organic forms to the environment, showing themselves contrary to any variation process. Robert Jameson (1774-1854), professor of Natural History in Edinburgh, published an adaptation of George Cuvier's texts under the title Essay on the theory of the Earth... (Edinburgh: printed for William Blackwood, John Murray \& Robert Baldwin, 1813) in which the Biblical Flood catastrophes were identified. This work, along with the interpretation of the geological data under the light of the Scriptures carried out by William Buckland (1784-1856) in his Vindiciae geologicae, or the connexion of Geology with Religion explained... (Oxford: at the University Press for the author, 1820) are good indicators of the influence of these theories in Great Britain during the first half of the $19^{\text {th }}$ century, whose structure was greatly influenced by the broad power of the Anglican Church's hierarchy in political and social life.

The counterpoint to this catastrophic 'geological flood' came from Charles Lyell's (1797-1875) work. In 1830 he started the publication of his influential

\footnotetext{
${ }^{23}$ Charles Darwin himself recalls it in his biography: "While I lived in London I often met with Owen, for I felt a great admiration but I was never able to understand his character and I never intimated with him. After the publication of The Origin of Species he became a very strong enemy. This was not due to any argument among us but, up to where I am able to judge, by the jealousy produced due to the success of the work..." (Charles Darwin [José Luis Gil Aristu, trans.]. Autobiografía. [Pamplona]: Laetoli, 2008; text on page 91 [supplied in Spanish]).

${ }^{24}$ Richard Owen. On the Archetype and Homologies of the Vertebrate Skeleton. London: J. Van Voorst, 1848.
} 
Principles of Geology... (London: John Murray, 1830-1833), in which he maintains that the actual geological structure is due to changes caused by slow and constant processes which act during vast periods of time. These geological processes, such as the wear of the rocks by the action of water, the marine tides, the continuous action of the waves on the coast, the volcanic activity or erosion, transport and sedimentation caused by the rivers, perfectly observable nowadays, are, according to Lyell's theory of uniformitarianism, the same as those that help us explain the changes produced in the complete history of the Earth. In his opinion, the constant changes in the physical geography were linked to modifications in the environmental conditions, that provoked variations in the fauna and flora - and also in the fossils - of the different regions of the Globe ${ }^{25}$. In Lyell's theorizing, Biogeography obtains a special importance as an element capable of nourishing his hypothesis. The ideas mentioned by Charles Darwin would have even more importance. Charles Lyell, whose theories influenced Charles Darwin's thinking, fiercely defended the stability of species. However, after reading The Origin of Species,... he would accept evolutionism ${ }^{26}$.

\section{Between Nature and Economy: the 'struggle for existence'}

The question about the dynamic balance of Nature was another of the topics discussed during the first decades of the $19^{\text {th }}$ century. The cleric William Paley (1743-1805) justified, in texts such as Natural Theology or, evidences of the existence and attributes of the deity... (London: printed for R. Faulder, Wilks and Taylor, 1802), the adaptation of the organisms to the environment and explained, as a result of this perfect harmony, the relations among hunters and their prey: only the weakest, those that cannot subsist anymore in an adequate manner, would fall in the power of their beater. William Paley's work was well known by Charles Darwin, for its lecture was mandatory in order to obtain a Degree in Arts by the University of Cambridge and, according to his commentaries, left a certain influence on his thoughts:

"The logic of this book [referring to Evidences of Christianity] and maybe also, Paley's Natural Theology caused as much pleasure as Euclides. A careful study of his works, without trying to memorise none of its parts, was the only one of my academic degree which was minimally useful to educate my thoughts, as it seemed to me at that moment, and still believe. At that time I was not worried about Paley's assumption and since they were accepted without critic, I liked his argumentative line, and he convinced me..." 27.

25 A biography of Charles Lyell in Carmina Virgili. El fin de los mitos geológicos. Lyell. Madrid: Nivola, 2003.

${ }^{26}$ A situation that even Charles Darwin comments: "He possessed a great and notable honesty and demonstrated it by changing to the theory evolution despite having obtained great fame by opposing Lamarck's theories. Even more, he did it at an elderly age..." (Charles Darwin [José Luis Gil Aristu, trans.]. Autobiografía. [Pamplona]: Laetoli, 2008; text - in Spanish - on page 88).

${ }^{27}$ Charles Darwin [José Luis Gil Aristu, trans.]. Autobiografia. [Pamplona]: Laetoli, 2008. Text - in Spanish - on page 55. 
However, years later, after reflecting upon the origin of species, his opinions about William Paley's theories had changed substantially:

"The old argument of Nature's design as exposed by Paley and that previously seemed to me so solid, failed after the discovery of the Natural Selection law. We cannot sustain anymore, for example, that the beautiful hinge of a bivalve shell should have been produced by an intelligent being, like the hinge of a door by a human. In the variability of the organic beings and in the effects of natural selection there seems to be no more indication than in the direction in which the wind blows..."28

The effect of the demographic pressure had had a doctrinal concretion in relation to human groups, in the formulations that Thomas Malthus (1766-1834) had carried out in 1798 when he published Essay on the principle of population... (London: printed for J. Johnson, 1798), in which he established the geometrical progression of human growth against the arithmetics of available nutritional resources in a way that the survival of the individuals was subordinated to social adaptation. The terms adaptation, development and progress were already related to the available literature of the time. The mechanisms which permitted to interpret this relation were still obscure when Charles Darwin started to work on the most classical of his works.

\section{The origin of On the Origin of Species...}

According to Charles Darwin himself he started to collect notes for The Origin of Species... shortly after he returned to England and strongly influenced by Charles Lyell's geological works (1797-1875):

"I started my first notebook in July 1837. I started working with the authentic Baconian principles, dispensed any theory and compiled all types of data, especially in what refers to domesticated species. For this, I appealed to printed questionnaires, conversations with skilled stockmen and gardeners and a great number of readings. When I see the list of books I have read, including complete collections of magazines and annuals, I surprise myself with my hard work..."29.

It did not take him long to find out that selection was the key to the success of artificial creation, but the way in which this principle could be applied to the natural world was a complete mystery for him.

In October 1838, fifteen months after having started his enquiries, he read (he maintains that "by casualty and to entertain myself") one of the books that shed new light on the problem, the Essay on the principle of population... (London, 1798) by Thomas Malthus (1766-1834).

\footnotetext{
${ }^{28}$ Charles Darwin [José Luis Gil Aristu, trans.]. Autobiografia. [Pamplona]: Laetoli, 2008. Text - in Spanish - on page 78.

${ }^{29}$ Charles Darwin [José Luis Gil Aristu, trans.]. Autobiografia. [Pamplona]: Laetoli, 2008. Text - in Spanish - on page 103-104.
} 
"There I finally had a theory on which I could work but I was very worried about trying to avoid any type of prejudice and I decided not to write anything during a certain period of time, not even a minor draft. In June 1842 I permitted myself, for the first time, the satisfaction of putting on paper, with a pencil and on 35 pages, a very brief summary of my theory, which I expanded during the summer of 1844 to 230 pages which I then copied with a legible handwriting and still conserve..."30

One of the most fundamental elements of On the Origin of Species... is not present in any of these papers: the natural tendency of living beings to branch off in their features as they are modified. The problem, and its solution, was addressed by Darwin some years later:

"I can remember this beautiful place in the street in which I felt the happiness of having thought of a solution while I was in my carriage. It was much later after I had moved to Down. The solution is, from what I think, that in Nature's economy, the modified offspring of all the dominating and in expansion forms tend to adapt themselves to many and very diversified places" ${ }^{31}$.

The main ideas that would form the central body of the work were already in his mind, the rest of the story is well known to us: spurred by Charles Lyell (1797-1875), Darwin started to write with great detail, "with an extension three or four times superior to the one that I maintained later in The origin of Species...", a compilation version of the cases on which he founded his hypothesis. In the summer of 1858, when he had hardly written half of the extensive discourse, he received Alfred Russel Wallace's (1823-1913) article On the tendency of varieties to depart indefinitely from the original type... An emergency solution was necessary in order to publish a short summary of Darwin's theory along with Wallace's papers and Darwin's famous letter to Asa Gray on September 5, 1857 in which he showed a draft of his theories, in the August 1858 Journal of the Proceedings of the Linnean Society. It was clearly a compromising solution:

"Nor the manuscript nor the letter to Asa Gray had been produced in order to be published and they were poorly written. On the other hand, Mr. Wallace's paper was wonderfully expressed and amazingly clearly written. However, our combined productions did not cause great attention and the only piece of news published about them that I can remember was that written by professor Haughton, from Dublin, whose verdict was that all the new things exposed in them were false and all the true things, old..."32.

${ }^{30}$ Charles Darwin [José Luis Gil Aristu, trans.]. Autobiografía. [Pamplona]: Laetoli, 2008. Text - in Spanish - on page 104. The texts have been converted into Spanish by Joan Lluis Riera. Charles Darwin \& Alfred Russell Wallace [Fernando Pardos, ed.]. La teoría de la evolución de las especies. Barcelona: Crítica, 2006.

${ }^{31}$ Charles Darwin [José Luis Gil Aristu, trans.]. Autobiografía. [Pamplona]: Laetoli, 2008. Text - in Spanish - on page 104-105.

32 Charles Darwin [José Luis Gil Aristu, trans.]. Autobiografía. [Pamplona]: Laetoli, 2008. Text - in Spanish - on page 105 . 
In September 1858, practically forced by Charles Lyell (1797-1875) and Joseph Dalton Hooker (1817-1911), Charles Darwin recovered his old notes and elaborated them once again - at a time when his poor health had worsened, compelling him to visit Dr. Lane's hydropathical hospital once again. He elaborated them out according to the format they would appear in, in November 1859, under the title On the origin of species..., a text that the author considered to be "the main work of my life".

The book obtained an immediate commercial success: the first edition, with 1,250 copies, was sold the same day of its publication, and the second edition, with 3,000 copies, shortly after. Where does the key of his success dwell? Darwin offers some elements:

"I think that the success of Origin can be ascribed in great measure to the fact that, long before, I had written two condensed drafts and I abridged a much longer manuscript which was already a summary of itself. This let me select the most striking data and conclusions. During many years I also followed a golden rule: to write immediately, and without delay, a note every time that I found myself with a new, or opposite to my general results, piece of published data, observation or thought..."33

He also refutes other interpretations:

"It has been said many times that the success of Origin demonstrated that 'the topic floated in the environment', or that 'the human mind was prepared for it'. I do not think that this is completely true because, once in a while, I asked not few naturalists and I never found any one of them that doubted the permanence of the species. Not even Lyell nor Hooker seemed to agree with me, even if they used to hear me with interest. In one or two occasions I tried to explain capable people what I understood by Natural selection but I vigorously failed..." 34

However, there is something in this refutation. On the one hand, the fact itself that such opinions were produced and, on the other hand, the heap of works, of one or other type, which come before Darwin's texts and which he himself mentioned in the 'Historical sketch' included in The Origin of Species... This sketch, that first appeared in the third edition, printed in April 1861, was orientated to comment both the progress of the acceptance of his theories and the acceptance of authors that, before him, had addressed the same problem. In it he pays special attention to an anonymous piece of work, Vestiges of the Natural History of Creation... (London: [s.n.], 1844), today attributed to Robert Chambers (1802-1871), a bookseller from Edinburgh. This work was another editorial success of the time ${ }^{35}$. In it we find a defence of the evolution of the organism based on modifications that take place during

33 Charles Darwin [José Luis Gil Aristu, trans.]. Autobiografía. [Pamplona]: Laetoli, 2008. Text - in Spanish - on page 106.

${ }^{34}$ Charles Darwin [José Luis Gil Aristu, trans.]. Autobiografía. [Pamplona]: Laetoli, 2008. Text - in Spanish - on page 107.

35 James A. Secord. Victorian Sensation. The extraordinary publication, reception, and secret authorship of Vestiges of the Natural History of Creation. Chicago: University of Chicago Press, 2001. 
the embryonic period, abnormally outstretched by external situations, leading to more advanced stages in the natural scale, whose last result would be the human being.

Charles Darwin knew how to value Robert Chambers' contributions within their real meaning:

"The work, because of its powerful and brilliant style, even though it shows little exact knowledge and a great lack of scientific concern in its first editions, had immediately produced a very extensive circulation. In my opinion, it has offered an excellent service to this country for having called the attention on this point, stirring worries and preparing the terrain for the reception of analogous opinions..."36.

To create a state of opinion, that was Robert Chambers' main contribution, a bookseller who knew very well the business he worked in; and, in one way or another, the idea of evolution was already present in the feelings of many who were just waiting to find an adequate and well supported formulation with strong arguments.

The precedents that Charles Darwin presents in 'Historical sketch' are many more. In it he made reference to the Natural selection hypothesis exposed by William Charles Wells (1757-1817), in the second decade of the $19^{\text {th }}$ century at the Royal Society ${ }^{37}$. He would also mention experiments on the cultivation of hyacinths carried out by William Herbert (1778-1847) ${ }^{38}$ and the hypothesis on the improvement of the descendents drafted out by Robert Edmond Grant (1793-1874) in his studies on Spongilla friabilis ${ }^{39}$. Darwin would also make reference to the opinion of the geologist Leopold von Buch (1774-1853), of neptunism training, in his Description physique des Isles Canaries... (Paris: F.-G. Levrault, 1836) ${ }^{40}$ and supported by the botanist Constantine Samuel Rafinesque-Schmaltz (1783-1840) ${ }^{41}$, according to who the varieties achieve constant features, little by little, until they become species. Of

36 Charles Darwin [Enrique Godínez, trans.]. Origen de las especies por medio de la selección natural ó la conservación de las razas favorecidas en la lucha por la existencia... Madrid / París: Biblioteca Perojo, 1877 (Quote - in Spanish - from page 6).

37 William Charles Wells. Two essays: on upon Single Vision with Two Eyes; the other on Dew. A Letter to... Lord Kenyon and an account of a female of the white race... part of whose skin resembles that of a negro... with a memoir of his life, written by himself. London: A. Constable and Co., 1818. The second of these papers, in which Charles Darwin centred his interest, was read in 1813 but not published until 1818.

38 William Herbert. Amaryllidaceae. London: J. Ridgeway and Sons, 1837.

39 Robert E. Grant. "On the structure and nature of Spongilla friabillis”. Edinburgh Philosophical Journal, 14: 270-284. Edinburgh, 1826.

${ }^{40}$ Leopold von Buch. Description physique des îles Canaries, suivie d'une indication des principaux volcans du globe, par Léopold de Buch. Traduite de l'allemand par C. Boulanger,... revue et augmentée par l'auteur. Paris: F.-G. Levrault, 1836. The original edition was published in German (Physicalische Beschreibung der Canarischen Inseln. Berlin: Koenigliche Akademie der Wissenschaften, 1825), but it was the French edition to which Charles Darwin made reference in his paper.

${ }^{41}$ Constantine Samuel Rafinesque-Schmaltz. New flora and botany of North America or a supplemental flora, additional to all the botanical works on North America and the United States, containing 1.000 new or revised species. In four parts. I. Lexicon and Monographs. II. Neophyton \&r. III. New Sylva \&c. IV. Neobotanon \&c. with introductions, sketches, notes, indexes, \& c . Philadelphia: [Printed for the author and publisher], 1836-1838. Charles Darwin mentions the first pages of the work (cf. pages 6, 18). 
course, he also had to make reference to the opinions that preceeded from his own family environment: his grandfather, Erasmus Darwin (1731-1802), presented his Zoonomy... (London: J. Johnson, 1794-1796), during the final years of the $18^{\text {th }}$ century, a pre-Lamarckist draft, that Charles Darwin read, first with admiration, and then with a certain disdain ${ }^{42}$.

These are, among many others, the predecessors of the Theory of Natural Selection which Charles Darwin wanted to have remembered. His son, Francis Darwin (1848-1925), left us a very different opinion:

"As a whole, I have the impression that the influence of the first evolutionists on his thoughts was priceless and in what refers to the story of The Origin of Species, has no particular importance, because (...) the theory of evolutionism did not thrive in his thought until he was notable to conceive the cause of the modification.

I think that Mr. Huxley [Thomas Henry Huxley (1825-1895)] is right when he states that 'It is not exaggerated to say that the biggest part of Darwin's work is the result of the decided application of the main idea to biology and of the applied method to geology [of Charles Lyell] in Principles..." 33 .

My opinion, and I think most of the Darwinists opinions, is totally favourable to the one issued by Francis Darwin who knew, maybe better than anyone, the birth of Charles Darwin's works.

42 “... reading it for the second time, after a discontinuity of 10 or 15 years, I suffered a great disappointment: his speculations are proportionally more in quantity in comparison to the contributed data..." (Charles Darwin [José Luis Gil Aristu, trans.]. Autobiografía. [Pamplona]: Laetoli, 2008. Text - in Spanish - on page 47)

${ }^{43}$ Charles Darwin. Autobiografía [Selección de Francis Darwin]. Madrid: Alianza, 1977 (translation from Aarom Cohen and María Teresa de la Torre, introductory study from Luís García Ballester. The mentioned text - in Spanish - belongs to volume 2: 263-264). 